\title{
Metastatic Bladder Carcinoma
}

National Cancer Institute

\section{Source}

National Cancer Institute. Metastatic Bladder Carcinoma. NCI Thesaurus. Code C156062.

A carcinoma that arises from the bladder and has metastasized to another anatomic site. 